\title{
腔粘表皮癌におけるメタロチオネインの免疫組織学的検討
}

\author{
伊藤道一郎·馬場信行 $\cdot$ 上谷 猛・冨永尚宏 \\ 徳久道生・空閑祥浩·水野明夫
}

\section{Immunohistochemical studies of metallothionein (MT) in oral mucoepidermoid carcinoma}

\author{
Michi-ichirou Itoun $\cdot$ Nobuyuki Baba $\cdot$ Takeshi Kamiya $\cdot$ Naohiro Tominaga \\ Michio Tokuhisa $\cdot$ Yoshihiro Kuga $\cdot$ Akio Mizuno
}

\begin{abstract}
Metallothionein (MT), a low molecular weight metal binding protein, has been implicated in the proliferative activity of carcinoma cells. In this report, tissue sections from six cases of mucoepidermoid carcinoma of the oral mucosa were studied immunohistochemically to characterize the expression of MT and to evaluate implications for tumor histological differentiation. The mean percentage of MT positive cells in the mucoepidermoid carcinomas $(3.1 \%, \mathrm{n}=6)$ was significantly lower than those in normal oral mucosa $(38.0 \%, \mathrm{n}=10)$ and oral squamous cell carcinomas $(56.0 \%, \mathrm{n}=7)$. When analyzed according to cell type of the mucoepidermoid carcinomas, $1.1 \%$ of the mucous cells, $4.7 \%$ of the epidermoid cells, and $1.7 \%$ of the intermediate cells were positive for MT immunoreactivity. The incidence of MT expression was significantly lower than that of the normal oral mucosa and the oral squamous cell carcinomas $(\mathrm{p}<0.001)$.
\end{abstract}

Key words: metallothionein（メタロチオネイン), mucoepidermoid carcinoma（粘表皮癌）

\section{緒 言}

唾液腺に生じる粘表皮癌は, 組織学的に多様な像を 呈し 1,2$)$, WHO 分類において悪性腫瘍に整理され ている ${ }^{3)}$. 本腫瘍は, 多くは外科的に摘出されるが, 低分化のものは悪性腫瘍の治療に準じ, 唾液腺の全摘 出術, 頸部郭清術, 放射線治療, 抗腫瘍性化学療法も 行われている.このような悪性腫瘍において, 治療方 針の決定や予後の判定に際し, 発育速度やその特性を 熟知することはきわめて重要である，そこで今回，粘 表皮癌の特性を知る目的で, 細胞増殖との関与が示唆 されているメタロチオネイン (以下 $\left.\mathrm{MT})^{4}\right)^{4}$ について, 免疫組織化学的に検討した.

長崎大学歯学部第一口腔外科学教室

(主任 : 水野明夫教授)

1 st Department of Oral and Maxillofacial Surgery, School of Dentistry, Nagasaki University (Chief: Prof. Akio Mizuno)

受付日：平成 7 年 12 月 20 口

\section{研究対象および方法}

\section{1. 研究対象}

粘表皮癌と診断し治療を行った 6 症例（1987 年 12 月より 1995 年 5 月) を対象とした.

対象症例はすべて一次症例で, 年齢は 49-80 歳, 平 均年齢は 64 歳, 性別は男性 4 例, 女性 2 例であった。 発生部位は口蓋および下顎歯肉がそれぞれ 3 例であっ た.また, 症状を自覚後来院までの期間は約 1 年以上 が全体の $83 \%$ で, 平均 3 年 9 か月であった（表 1 ).

\section{2. 研究方法}

生検および手術時に採取した組織片を，10\%中性ホ ルマリンにて固定後, 通法に従いパラフィン包埋し, $4 \mu \mathrm{m}$ の連続切片を作製した. 切片は, 抗 MT 抗体 (DAKO-MT, E 9 ) による免疫組織染色法 (アビジンビオチンーペルオキシダーゼ複合体法, ABC 法)にて 染色した。発色にはAEC (aminoethyl carbozole) を用い, マイヤー・ヘマトキシレンで核染色後, 脱水 封入し検鏡を行った. なお, 免疫反応の特異性検定の ための吸収試験は, 第 1 抗体とその抗原を反応させて 同一の方法で染色を行った．その結果，反応は完全に 消失したので, 今回の染色は特異的であることが確認 
表 1 病理組織学的分類および MT 陽性率

\begin{tabular}{|c|c|c|c|c|c|c|c|c|}
\hline \multirow[b]{2}{*}{ 症例 } & \multirow[b]{2}{*}{$\begin{array}{l}\text { 年齢 } \\
\text { 性別 }\end{array}$} & \multirow[b]{2}{*}{$\begin{array}{l}\text { 初発から初診 } \\
\text { までの期間 }\end{array}$} & \multirow[b]{2}{*}{$\begin{array}{l}\text { Grade 分類 } \\
\text { (1978, 小守ら })\end{array}$} & \multirow[b]{2}{*}{$\begin{array}{c}\text { WHO 分類 } \\
(1991)\end{array}$} & \multicolumn{4}{|c|}{ MT 陽性率（\%） } \\
\hline & & & & & $\begin{array}{l}\text { 粘液産 } \\
\text { 生細胞 }\end{array}$ & $\begin{array}{c}\text { 扁平上皮 } \\
\text { 様細胞 }\end{array}$ & $\begin{array}{l}\text { 中間 } \\
\text { 細胞 }\end{array}$ & $\begin{array}{l}\text { 平均陽 } \\
\text { 性率 }\end{array}$ \\
\hline 1 & 49/女 & 3 年 & II & low & 2.1 & 4.0 & 0.8 & 2.8 \\
\hline 2 & 61/男 & 1 か月 & II & low & 0 & 8.4 & 0.1 & 2.3 \\
\hline 3 & 49／男 & 1 年 & II & low & 4.6 & 7.6 & 0.1 & 4.1 \\
\hline 4 & 74 /男 & 15 年 & II & high & 0 & 5.9 & 2.9 & 3.8 \\
\hline 5 & 69 /男 & 1 年 4 か月 & II - III & high & 0 & 1.9 & 2.3 & 2.4 \\
\hline 6 & 80 /女 & 1 年 2 か月 & II - III & high & 0 & 0.1 & 3.7 & 3.4 \\
\hline 平均 & 63.7 & 3 年 9 か月 & & & 1.1 & 4.7 & 1.7 & 3.1 \\
\hline
\end{tabular}

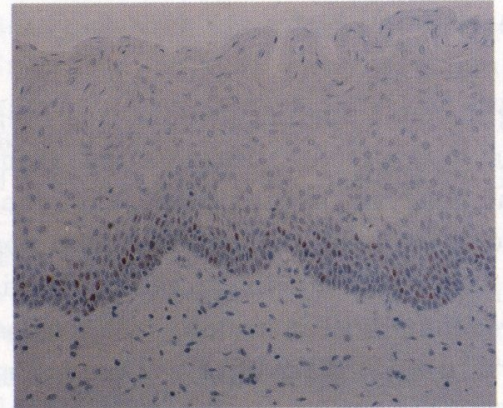

図 1 正常粘膜における MT 免疫染色 $(\times 100)$ 基底層に著明な MT 陽性細胞が認められる。

された。また，対照群として正常部の口腔粘膜 $(\mathrm{n}=10)$ および, 口腔扁平上皮癌症例 $(\mathrm{n}=7)$ を用い た.MT 陽性率（\%)は, 腫瘍組織における MT 陽性 細胞の占める割合を指標とし，実際には一標本あたり 10 力所から無作為に選択し，2500-3000 個の腫瘍細胞 を観察し，その腫瘍細胞数に対する MT 陽性細胞数の 平均を百分率で算出し, MT 陽性率とした。統計学的 検索には, $\mathrm{t}$ 検定を用いた。

\section{結果}

\section{1. 病理組織学的所見}

対象症例 6 例の分化度をみると中等度の分化を呈す るもの (Grade II ) 4 例 (66.7\%), 中等度ないし分化 が低いもの（Grade II - III）2 例（33.3\%）であった. また, WHO分類では well differentiated type (low grade malignancy) が 3 例 (50\%), poorly differen tiated type (high grade malignancy) が 3 例 (50\%) であった。

\section{2. 免疫組織化学的所見}

1) MT の分布：口腔粘表皮癌 6 症例の全例に, MT 陽性細胞の割合は非常に少ないが認められた. 腫 瘍細胞の核あるいはまた細胞質に陽性であるものが確 認できた. MT 陽性細胞の胞巣内の分布は, 浸潤方向 と思われる腫瘍胞巣周辺部に MT 陽性細胞が多数認 められた. 正常口腔粘膜では MT は基底層の細胞の核

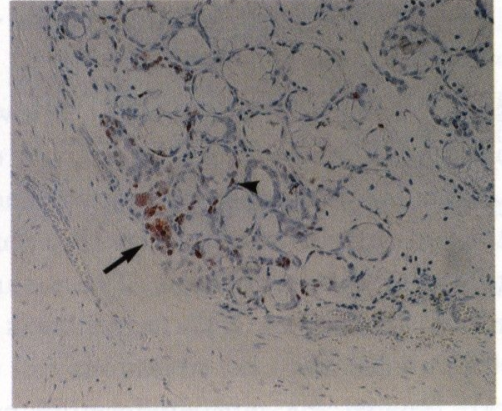

図 2 症例 3 (Grade II ) における MT 免疫染色 $(\times 100)$ 粘液細胞 (矢頭) および中間細胞 (矢印)に MT 陽性細胞 が認められる.

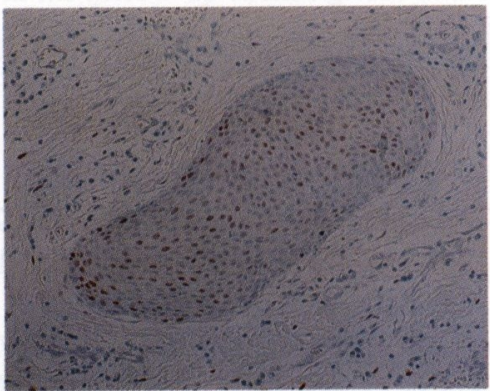

図 3 症例 2 (Grade II) における MT 免疫染色 $(\times 100)$ 扁平上皮様細胞に MT 陽性細胞が認められる.

に分布していた（図 1). 粘表皮癌では, 粘液細胞を主 体とする胞巣 (図 2 ), 扁平上皮様細胞で構成される 胞巣 (図 3 ), およびその中間型の細胞で構成される 胞巣（図 2 ）に MT の陽性細胞が分布していた.

2) MT 陽性率: 口腔粘表皮癌 6 例の MT 陽性率は 平均 $3.1 \pm 0.7 \%$ で, 正常粘膜上皮 10 例における $\mathrm{MT}$ 陽性率の平均 $38.0 \pm 7.0 \%$ お よび口腔扁平上皮癌一次 症例 7 例の $56.0 \pm 18.0 \%$ と比較し, 有意水準 $0.1 \%$ 以 下で有意差を認めた（図４）。なお，WHOによる組織 学的分類別では, MT の平均陽性率は well differentiated type (low grade malignancy) が $3.1 \%$, poorly differentiated type (high grade malignan- 


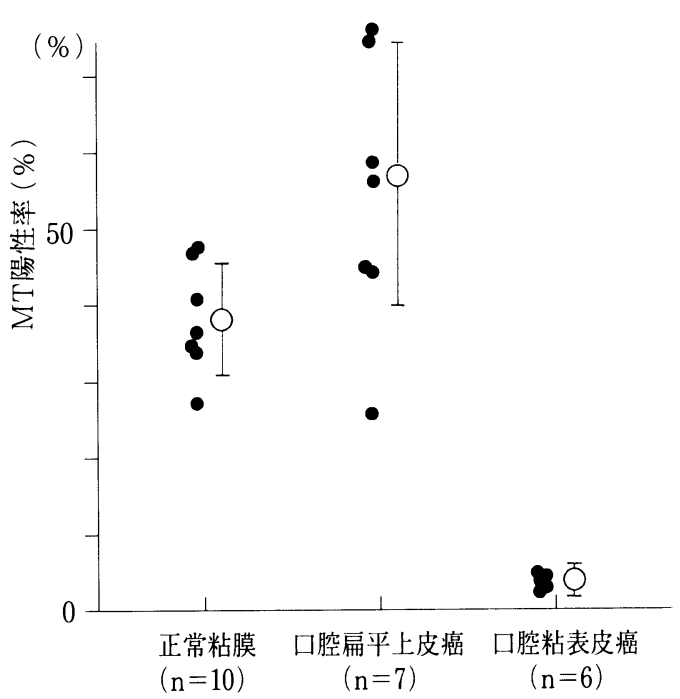

図 4 正常粘膜，扁平上皮癌および粘表皮癌における MT 陽性率

cy）が $3.2 \%$ ，両者間に有意差はみられなかった。 粘表皮癌を構成する各細胞の平均 MT 陽性率は, 粘液 産生細胞が $1.1 \%$, 扁平上皮様細胞が $4.7 \%$, 中間細胞 が $1.7 \%$ であった（表 1 ）.

\section{考察}

MTの発現に関してラットなどにおける免疫組織染 色では, 増殖能の盛んな胎児, 新生児, さらに, 再生 肝などで核内での強い染色性が認められている $\left.{ }^{5}, 6\right)$. このような高い増殖能をもつ細胞における MT 誘導 は, 培養腫瘍細胞においても報告されている ${ }^{7)}$. ヒト 甲状腺腫瘍における MT の免疫染色の報告 ${ }^{8)}$ はある が, MT 陽性細胞の割合については言及していない. 本症例研究群での MT 陽性細胞の割合は, 腫瘍全体と しては非常に少ないが, 浸潤方向と思われる腫瘍胞单 周辺部の腫瘍細胞の核および胞体に強い染色性が認め られた。よって, MT が口腔粘膜上皮と口腔由来の腫 瘍の細胞増殖に関わっている可能性が充分考えられた.

本研究対象の粘表皮癌症例の $\mathrm{MT}$ 陽性率は, 平均 $3.1 \%$ で，口腔粘膜上皮細胞の $38 \%$ に比べ有意に低值 を示した。もし，MTの発現が単に細胞の増殖に関与 しているものであれば, 今回検討した粘表皮癌症例の 腫瘍細胞の増殖能は非常に低いものと考えられる. Robert ら 9) の粘表皮癌の PCNA（Proliferating cell nuclear antigen) 陽性率は, 平均 $7 \%$ で, Grade I , II の PCNA 陽性率は，ほとんどが $10 \%$ 以下で予 後も良好であった。しかし, Grade IIIになると PCNA 陽性率は 20-50\%と高值を示し, 非常に予後不良であっ た，本報告症例群においては，症状自覚後初診までの 期間は平均 3 年 9 か月で, 1 例を除いてすべて 1 年以
上の期間を経ており，また，現在のところ再発もなく 経過良好である。このことは, 組織学的分類が Grade IIであったこと, さらには, MT 陽性率および MT 局 在が PCNA と似た傾向を示したことと関連している のかもしれない.

\section{結語}

1. 口腔粘表皮癌の特性を知る目的で，口腔粘表皮 癌細胞におけるメタロチオネイン $(\mathrm{MT})$ の発現につ いて, 免疫組織化学的検討を行った.

2. 口腔粘表皮癌 6 例における MT の平均発現率は $3.1 \%$, 正常口腔粘膜細胞および口腔扁平上皮癌に おける MT の発現率に比べ非常に低い值を示した.

稿を終えるにあたり, 免疫染色に関して格別の御配慮 を頂いた長崎大学医学部第三解剖学講座中根一穂教授, 小路武彦助教授, 和泉伸一先生, および島根医科大学第 二外科学教室菱川善隆先生に心より感謝の意を表します.

\section{引用文 献}

1）石川梧朗監修: 口腔病理学 II. 改訂版, 永末書 店, 京都, 1982, 740-745 頁.

2) 小守 昭 : 小喠液腺腫瘍一病理一, 病理と臨床 8 : 844-855 1985 .

3) Seifert, G.: Histological typing of salivary gland tumors.; 2 nd Ed, SpringerVerlag, Berlin, 1991, p20-21.

4) Suzuki, K.T., Imura, N., et al.: Metallothionein III . Birkhauser Verlag, Basel, 1993.

5) Nishimura, H., Nishimura, H. et al.: Immunohistochemical localization of metallothionein in developing rat tissues. J Histochem Cytochem 37: 715-722 1989.

6) Tohyama, C., Nishimura, H., et al.: Immunohistochemical localization of metallothionein in the liver and kidney of cadminum or zinc treated rats. Act Histochem Cytochem 21: 91-102 1988.

7) Karin, M. and Herschman, H.R.: Dexamethasone stimulation of metallothionein synthesis in Hela cell culture. Science 204: 176-177 1979.

8) Nartey, N., Cherian, M.G., et al.: Immunohistochemical localization of metallothionein in human thyroid tumors. Am J Pathol 129: 177-182 1987.

9) Robert, F.A., El-Naggar, A.K., et al.: High correlation with survival of proliferating cell nuclear antigen expression in mucoepidermoid carcinoma of the parotid gland. Oto laryngol Head Neck Surg 111: 460-466 1994. 